\title{
Yellow oleander poisoning : a case report
}

\author{
Mollah $\mathrm{A} \mathrm{H}^{1}$, Ahmed $\mathrm{S}^{1}$, Haque $\mathbf{N}^{1}$ \\ Shamsuzzaman ${ }^{1}$, Islam A K M N ${ }^{1}$, Rashid A ${ }^{2}$, Rahim $\mathbf{M}^{3}$
}

\section{INTRODUCTION}

Because of its beautiful flowers, people plant yellow oleander tree in their garden \& compound as a hobby without knowing it's poisonous action. The entire plant is toxic including smoke from the burning foliage and even the water in which the flower have been placed. ${ }^{1,2}$ Yellow oleander has been used for the purpose of suicide, homicide and as an abortifaecient ${ }^{3}$ and if anybody ingests any part of it accidentally, this may apprehend a fatal outcome $^{4,5}$ and even the fetus can be affected if the pregnant mother ingests it. ${ }^{6}$ Recently a 7 years old boy was admitted into pediatric ward of Dhaka Medical College Hospital (DMCH) in a serious condition by ingesting seeds $\&$ fruits of yellow oleander accidentally in his school compound \& it is here documented to aware the health professionals about its toxic effects and the appropriate management.

\section{CASE SUMMARY}

A 7 years old school boy was admitted on $15^{\text {th }}$ June 2001 with a history of ingestion of a fruit along with its seeds from a yellow oleander tree in the premises of his school as he thought it was a water chestnut (there is a structural similarity between water chestnut $\&$ yellow oleander fruit). About 20 minutes following ingestion, he started vomiting \& became restless. Subsequently he became drowsy, lethargic $\&$ had froth from his mouth and passed loose stool unconsciously. On examination, the child was found mildly dehydrated with cold \& calmly extremities. His pulse rate was $54 / \mathrm{min}$, low volume \& irregular. Blood pressure was $60 / 20 \mathrm{~mm} \mathrm{Hg}$. Respiration was shallow \& rate was $28 / \mathrm{min}$. Heart sound was audible $\&$ irregular. Pupils were slightly dilated with sluggish reaction to light. The child was resuscitated quickly with oxygen, intravenous fluid and injection atropine $(0.02 \mathrm{mg} / \mathrm{Kg})$ and his cardiovascular and

Key Words: Poisoning, yellow oleander, digitalis, arrhythmia.

1. Dept. of Pediatrics, Dhaka Medical College \& Hospital.

2. Dept. of Pediatrics, Bangladesh Medical College \& Hospital.

3. Dept. of Cardiology, Dhaka Medical College \& Hospital.

Address for correspondence : Dr. Md. Abid Hossain Mollah

Associate Professor of Pediatrics

Dhaka Medical College \& Hospital, Dhaka, Bangladesh

Email: navid@bdonline.com 


\section{Fig. 1}

Fig. 2

Fig. 3

\section{Fig.3 : Normal Sinus Rhythm on Day - 3 (18.06.01)}

haemodynamic status was monitored closely in Coronary Care Unit. Gastric lavage was also given. Atropine required to repeat after 5 minutes of first dose. ECG on admission showed varying types of arrhythmia (bradycardia, multiple extrasystoles, second degree heart block with intermittent complete heart block) and electrolytes revealed hyperkalaemia (serum $\mathrm{K}^{*} 6 \mathrm{mmol} / \mathrm{L}$ ) \& acidosis (serum bicarbonate $16 \mathrm{mmol} / \mathrm{L}$ ) respectively. Chest X-ray was found normal. His biochemical \& electrocardiographic parameters were followed up everyday and with these measures, the child became well \& he was discharged on the $10^{\text {th }}$ day of hospitalization.

\section{DISCUSSION}

Poisoning from yellow oleander is not uncommon and has been reported from different parts of the world., ${ }^{4,7}$ The tree has different names in different countries like cerbera thevetia, pilakane. ${ }^{10}$ In Bangladesh, it is popularly known as 'karobi' and is 
planted widely because of its graceful flowers. It's fruits are attractive to children. ${ }^{11}$ The tree is also used as medicinal plant. ${ }^{2,9}$ However, the actual incidence of poisoning from it in Bangladesh is not known. In this subcontinent, Srilanka has the highest reported incidence of yellow oleander poisoning because the seeds of yellow oleander is known there as 'lucky nuts' and every year many people ingest it with some having consequent fatal outcome. 9,12

Incidence of poisoning could also be higher in countries or communities where people rely mostly on herbal medicines that might include yellow oleander product. ${ }^{9}$ The fatal dose is uncertain. Ingestion of only 8-10 seeds can cause death of an adult within 24 hours but it is reported that ingestion of only one seed resulted death of a 4 years old child. ${ }^{3}$

The active principle of this plant products are 3 glycosides namely thevetin $(\mathrm{A}+\mathrm{B})$, thevetoxin \& cerebrin. Both thevetin \& thevetoxin are cardiotoxic \& their actions resemble that of digitalis. ${ }^{10,11}$ On the other hand, cerberin has an action like strychnine. ${ }^{10}$ These cardiac glycosides affect cardiovascular system (CVS), central nervous system (CNS) \& gastrointestinal system. Of these, effects on CVS are most important. The toxins after binding to a site on cell membrane, produce reversible inhibition of $\mathrm{Na}^{+} \mathrm{K}^{+}$Adenosine Triphosphatase pump which causes increased intracellular $\mathrm{Na}+\&$ decreased intracellular $\mathrm{K}+$. This elevated intracellular $\mathrm{Na}+$ concentration allows more $\mathrm{Ca}++$ influx into the myocardial cells via a $\mathrm{Na}^{+}-\mathrm{Ca}^{++}$exchanger. As a result of excessive $\mathrm{Ca}++$ within myocardium, widespread cardiac contraction occurs \& manifest clinically as premature ventricular contractions. ${ }^{9}$ Cardiac glycosides also have vagotonic effects resulting in bradycardia $\&$ heart blocks. ${ }^{9}$ In addition, inhibition of $\mathrm{Na}^{+}-\mathrm{K}^{+}$ATPase in skeletal muscle results in excess $\mathrm{K}+$ in extra cellular fluid with concomitant manifestations of hyperkalaemia. ${ }^{1,9,13}$
Hypophosphatemia associated with yellow oleander poisoning has also been reported. ${ }^{13}$

The common clinical features of yellow oleander poisoning are burning sensation in mouth with tingling of tongue, dryness of throat, automaticity of heart \& different types of arrhythmia. Along with these, vomiting, diarrhea, headache, dizziness, dilated pupils may also occur. Sometimes patients become drowsy, comatose \& eventually die and occasionally there could be tetanic convulsion. ${ }^{3,10}$ Our patient presented with varying types of arrhythmia and features of shock along with vomiting, restlessness, and lethargy and altered consciousness. Similar predominant cardiac manifestations were also noted by other authors..$^{5,14,15}$ Therapy is directed at decontamination of poison, continuous monitoring in $\mathrm{CCU}$, checking electrolytes at frequent interval and correction of imbalance if any. ${ }^{9,11}$ In hyperkalaemia, which is most common, Glucose (0.5 - $1.0 \mathrm{gm} / \mathrm{kg}$ ) and Insulin (1 unit regular insulin per $3 \mathrm{gm}$ glucose) may be used. ${ }^{9}$ Similarly, sodium bicarbonate (1-2 $\mathrm{mEq} / \mathrm{kg}$ ) may be used in acidosis. ${ }^{9}$ Atropine is used to treat bradyarrhythmia and phenytoin, lignocaine or propranolol can be used to treat tachyarrhythmias. ${ }^{7}$ If these measures fail or the patient shows signs of significant poisoning, treatment with digoxin-specific Fab antibodies may be used to reverse oleander toxicity. ${ }^{9,11,13,16}$ Failure at this juncture would require continued inotropic support and the insertion of a cardiac pacemaker. ${ }^{9,11,17}$ Our patient had bradycardia and was managed with injection of atropine \& other supportive measures with attention to Airway, Breathing and Circulation. Gastric lavage was given which is recommended ${ }^{5,9,13}$ though some authors opine that ipecac is more effective to induce vomiting in this regard. ${ }^{18}$ Sometimes activated charcoal (1-2 gm/ $\mathrm{kg}$ ) and cholestyramine is used orally to prevent absorption. ${ }^{18}$ In our case, treatment with drugs other 
than atropine were not required as the total follow up parameters gradually showed significant improvement. The role of forced diuresis and dialysis as well as use of steroid \& epinephrine is doubtful and is not recommended. ${ }^{11,18}$

The outcome of yellow oleander poisoning depends on the amount of the plant ingested and how quickly the management has started and complete recovery is likely if the patient survives the first 24 hours of ingestion..$^{18}$ This child was brought to hospital within an hour of ingestion and resuscitation was done promptly with the assistance of cardiology department and perhaps this saved him from this deadly poison. Prognosis is usually good. ${ }^{18}$

\section{REFERENCES}

1. Kenneth F. Toxic effect of plant toxins. In : Cortis D K, Mary 0 A, J ohn D, Third edition. Casarett and Doull's Toxicology : The Basic Science of Poisons. New York, USA : Mac millan Publishing Company, $1986: 762$.

2. Davies M K, MayneA J. Oleander poisoning. Arch Dis Child, 2001 Jan; 84 (1) : 9.

3. Franklin C. A. Cardiac Poisons. In : Franklin C.A, 21st edition. Modi's Text Book of Medical J urisprudence and Toxicology ; Bombay, India : N M Tripathi Pvt. Ltd., 1988: 278.

4. Brewster D. Herbal poisoning : a case report of a fatal yellow oleander poisoning from the Solomon Islands. Ann Trop Paediatr, 1986 Dec; 6 (4): 289-91.

5. Ahlawat S K, Agarwal A K, Wadhwa S. Rare poisoning with cerebra thevetia ( yellow oleander): a report of three cases. Tropical Doctor, 1994; 24 : 37-38.

6. Thilagar $\mathrm{S}$, Thirumalaikolundusubramanian $\mathrm{P}$, Gopalakrishnan R, Lakshmikandan R, Ayyappan A, SubramanianR. Possible yellow oleander poisoning in a neonate. Indian Pediatrics, 1986 ; $23: 393$.

7. Cheung K, urech R, taylor L, Duffy P, Radford D.
Plant cardiac glycosides and digoxin Fab antibody. J Paediatr. Child Health, 1991; 27 : 312-313.

8. Ansford A J, Morris H. Fatal oleander poisoning. Med J Aust, 1981 April; 1(7) : 360-361.

9. Douglas R. L. Plant Poisoning, E-Medicine J ournal, May, 2001, 2(5): 1 (www.acep.org)

10. Parikh C. K. Cardiac Poisons. In : Prabhakar PE, Gargi J. $5^{\text {th }}$ Ed : Parikh's Text Book of Medical J urisprudence and Toxicology. Bombay, India : C B S Publishers \& Distributors, 1990, 927-8.

11. Donals B K, George B. Poisonous plants. In : Haddad L M, Shannon M W, Winchester J F, $3^{\text {rd }}$ edition. Clinical Management of Poisoning \& Drug overdose. Philadelphia, USA : W B Saunders, 1998 : 383-84.

12. Saravanapavananthan N, Ganeshamoorthy J. Yellow oleander poisoning -a study of 170 cases. Forensic Sci Int, 1988 ; 36 ( 3-4): 247-50.

13. Safadi R, Levy I, Amitai Y, Caraco Y. Beneficial effect of digoxin-specific Fab antibody fragments in oleander intoxication. Arch Intern Med, 1995; 155: 2121-2125.

14. Samar K K, Sahu H.K, Kar M K, Palit S K, Kar B C, Sahu C S. Yellow oleander (cerebra thevetia), poisoning with jaundice and renal failure. J Assoc Physicians, India, 1989 ; 37 (3): 232-33.

15. Samar K K, "Yellow oleander poisoning with jaundice and renal failure" J Assoc Physicians India., 1990 ; 38 (10): 821-22.

16. J ortani S A, Helm R A, Valdes R J r. Inhibition of $\mathrm{Na}, \mathrm{K}$ - ATPase by oleandrin and oleandrigenin and their detection by digoxin immunoassays. Clinical Chemistry, 1996 ; 42 (10) : 1654-1658.

17. Avasthi R.. Yellow oleander poisoning. J. Assoc. Physicians India, 1991; 38 (3) : 250.

18. Dreisbach $\mathrm{R} \mathrm{H}$. Emergency management of poisoning.. In : Dreisbach $\mathrm{R} \mathrm{H}$; $9^{\text {th }}$ edition, Hand Book of Poisoning. Los Altos California : Lange Medical Publication, 1977 : 365-6. 